\title{
COMMERCIAL DIPLOMACY IN A GLOBALIZED WORLD
}

The beginning of $21^{\text {st }}$ century has witnessed the consolidation of a process of globalization that expanded through the second half of the past century, primarily after the end of the Cold War and the fall of the communist regimes. Today's global economy is in transition from a world leaded by the United States and other advanced economies, such as Japan and the European Union, to a multipolar system, where emerging economies such as Brazil, Russia, India and China (the so-called BRIC) are increasing their international influence and entering and investing in developed markets. Nevertheless, this does not mean that industrialized economies are going to decline in prosperity because of the rise of emerging economies. On the contrary, this shift in the global economic balance of power may be an opportunity for advanced economies to prosper in the future if they are able to adjust to the new situation.

Many conventional trade barriers have decreased or been removed over the last years (probably the best example of this is the creation of an internal and single market among all members of the European Union), and it gives the impression that such tendency will continue in the future (for instance, if the Transatlantic Trade and Investment Partnership (TTIP) is finally approved between the European Union and the United States). Thus, since formal trade barriers are being progressively reduced and transportation has become much cheaper, other factors such as cultural and institutional distance have gained prominence in international trade relations. Van Veenstra et alt. distinguish between four categories of current barriers to trade:

1) lack of export knowledge (informational barriers);

2) internal resource constraints (financial or human resources);

3) procedural barriers (language, cultural differences, red tape);

4) exogenous barriers (fluctuations in the exchange rate, taxation, corruption, etc.) (Van Veenstra, Yakop, van Bergeijk, 2010: 5).

These barriers exist most of all in economies of non-OECD countries where foreign firms often face troubles when trying to obtain different permissions and to deal with restrictions and controls. Delivery in developing countries is slower and less reliable and quality and service levels are usually lower. Firms in developing countries also find obstacles when exporting because quality standards abroad in OECD states are often higher than domestic standards and make them more difficult to compete in foreign markets.

In all cases, entry into new foreign markets requires a good knowledge of foreign legislation, cultural differences and local preferences, and the search for an evalua- 
tion of potential international business partners is costly and time-consuming. Firms also need to have access to reliable and neutral information, enhance their credibility and image and be able to handle conflicts effectively. However, private companies rarely invest in acquiring knowledge by themselves. Exporting requires an investment that is considerably risky (Van Veenstra et alt., 2010: 6). If it fails, the investment does not return, and if it succeeds, the strategy will be copied by competitors that will take advantage of somebody else's work. In addition, expropriation problems and market failures may happen under some political and economic situations, and then it is better to count on the home country government's involvement (Yakop, van Bergeijk, 2009: 10).

This is why corporations prefer to invest too little in trade-relevant knowledge and choose to trust public intervention in general and commercial diplomacy in particular to carry out such significant mission. To support these export activities, government policies may improve certain characteristics of a firm and help occasional exporters to become permanent exporters. However, in order to do that, resources must be properly allocated and some sort of pre-selection is necessary, so that only the most productive firms are assisted in their internationalization process (Van Veenstra et alt., 2010: 6).

In some cases, the promotion of a developed country exports to low-income states is even part of a wider foreign policy, which is designed to create a more diversified and competitive local economy and to facilitate the transition to democratic government in the host country. This has been the case of U.S. programs emerged through the 1990s in Central and Eastern Europe and the former USSR. Here commercial diplomats do not only work to increase exports, to raise the number of exporters and to defend their home country commercial interests (Ford, 2005: 24). By pursuing the opening of new free markets, global economy is further liberalized and global competition becomes even keener, to the ultimate benefit of all nations. Therefore commercial diplomats play an important political role in the development and democratization of the host country as well as in the defence of freedom and the opposition to tyranny (Ford, 2005: 26-27).

Until the 1980s diplomacy was usually considered as the dialogue between states, since no other diplomatic actors were recognized yet. However, after the end of the Cold War and the subsequent changes in global economy, states stopped being the only players in the diplomatic stage, and new actors (such as supranational organizations, NGOs and international businesses among many others) turned into active participants of contemporary diplomatic and business environment. Firms need diplomacy to gain foreign market access and to negotiate in foreign market environments, and governments need diplomacy to get foreign firms investing in their home states and to protect their home firms operating abroad. Consequently, in this era of globalization, export promotion and inward investment promotion are completely interlinked. All these changes in the recent past have evidenced the need for the development of a full set of tools for a commercial diplomacy driven by close nation-state-business collaboration and diplomatic support for international business. For all these reasons, commercial diplomacy should be treated as one of the most important components of overall diplomacy. 


\section{CHARACTERISTICS AND FUNCTIONS OF COMMERCIAL DIPLOMACY}

The definition of commercial diplomacy is used to cover many different types of activities. Some of those activities (also referred to as trade diplomacy, such as multilateral trade negotiations, trade consultations and dispute settlement), are designed to influence government policy and regulatory decisions that affect global trade and investment. However, Kostecki and Naray prefer to use the term commercial diplomacy to cover business-support activities performed by the members of diplomatic missions, their staff and the related agencies. They believe that the term commerce can cover broader issues than the term business. Commerce refers not only to trade but also to those activities related to investment, tourism or intellectual property. Kostecki and Naray define commercial diplomacy as ,a government service to the business community, which aims at the development of socially beneficial international business ventures" (Kostecki, Naray, 2007: 1-3). According to them, commercial diplomats perform most of their activities in the state, as for example relations with different government departments, civil servants, parliament, NGOs, business organizations, corporations and so on. These diplomats are usually staff members of a diplomatic mission or a trade promotion organization (TPO)/investment promotion agency (IPA).

For Yakop and van Bergeik commercial diplomacy is ,the use of international political tools (diplomacy) to obtain economic objectives" (Yakop, van Bergeijk, 2009: 8). For them, commercial diplomacy refers to the activities carried out by public officials from diplomatic missions, Foreign Affairs and other government departments, aimed to support the promotion of foreign direct investment and international trade by supplying information and advice about trade and investment opportunities and by organizing and helping to act as hosts to trade missions from the home country.

Mercier defines commercial diplomacy as ,the art, or the science, of helping a country's enterprises trade abroad and to convince foreigners of the advantages of investing in the home country. This task is usually pursued through a network of public and private actors that include governmental staff, business leaders, chambers of commerce and associations" (Mercier, 2007: 25). For him, the concept of commercial diplomacy is usually interpreted in two ways. On a more general level, ,as being a part of economic diplomacy", that is related to economic policy issues. This broad definition seems more concerned with negotiations of trade agreements and their implementation. If narrowed on a micro level, the definition of commercial diplomacy focuses on „supporting trade and inward as well as outward investment” (Mercier, 2007: 3). For its part, Berridge and James' definition of commercial diplomacy refers to "the work of diplomatic missions in support of the home country's business and finance sectors" and includes ,the promotion of inward and outward investment as well as trade" (Berridge, James, 2001: 38-39).

Saner and Yiu distinguish economic diplomacy from commercial diplomacy. The first is connected with the actions taken by different specialized ministries to influence the structure and mechanism of global of global governance in economic and trade arenas policy issues, e.g. works of delegations at standard setting organizations such as the World Trade Organization (WTO). Economic diplomats also monitor and report on policies in foreign countries and then give their home government advice 
on how to best influence them. To pursue a particular foreign policy objective, economic diplomats employ economic resources such as rewards or sanctions (Saner, Yiu, 2003: 12-13).

But governments can also support national economic development by providing support to their own enterprises in different forms such as export advice or legal assistance. At the same time, their function can include the provision of support to foreign enterprises interested in investing in the respective country. And this is what commercial diplomacy is about. Commercial diplomatic missions work in order to support the sending state's business and finance sectors in their pursuit of economic success and with the final objective of the state national development. Commercial diplomats promote both inward and outward investment and trade, and their work includes the supplying of information about export and investment opportunities and the organization and help to act as hosts to trade missions from home.

First objective of commercial diplomacy is increasing import, export, and international trade; but in the long term, ultimate and indirect objectives are economic growth and prosperity. Two main types of activities of commercial diplomacy can be differentiated in the processes of achieving these goals. In first place commercial diplomats cover primary activities. These are marketing-related, and among them there are activities such as promotion in trade fairs, exhibition, conferences or business and export promotion campaigns. Commercial diplomats focus most of their efforts on attracting Foreign Direct Investments (FDIs) that help stimulate the home country economic growth and employment in priority sectors or regions. Secondly, commercial diplomats' activities involve also cooperation in research and technology and collaboration in the promotion of different national services such as tourism, banking or education.

In the past, diplomatic and consular missions, while representing the home country abroad, were the eyes and ears in the host state and the most important source of information for future investors. Nowadays, the informational role of the Foreign Affairs Services, although still important, has been pushed into the background due to the fall of communications costs and the progressive easiness to access to information from and about other countries. Today, diplomatic and consular missions are more occupied with the promotion of the economic and commercial interests of the sending state in the host state and are important actors in commercial diplomacy, since they are in position to provide relevant information, build trust, attract business and imports towards the domestic economy, and be publicly involved in the promotion of exports (Van Veenstra et alt., 2010: 7-8).

One of the most important primary responsibilities of the commercial diplomats is the advocacy of the commercial diplomacy for the national business community. Kostecki and Neray describe this advocacy as ,the involvement of the commercial diplomat in public affairs for the benefit of national companies and business associations in their dealings with the host country government, parliament or main public institutions" (Kostecki, Naray, 2007: 9). For them it also means that commercial diplomats have to react to host country proposals for regulations and international trade agreements. Furthermore, commercial diplomats work very often in cooperation with TPOs/IPAs or bilateral chambers of commerce, and in many cases they act simultaneously as commercial advisors of the embassy and as directors of these TPOs/IPAs (Kostecki, Naray, 2007: 8-9). 
Among the support activities that provide the inputs needed for the primary activities to occur, the most important labour of commercial diplomacy is intelligence, which includes information search and dealing with business enquiries from the home and host country firms. This service is mainly required by small and medium-sized enterprises (SMEs) that ask for basic information on aspects such as legal issues, changes in regulations, political situation and so on rather than by larger firms. Support activities also include the creation of networks in order to bring together high tech start-ups with venture capitalists or other partners; involvement in image campaigns that are crucial for FDI promotion and in many cases entail ambassador's contacts with CEOs of large firms and attendance at business for and in the host country; or the need to establish good relations with business leaders and authorities with the goal of protecting the sending state's business interests in public hearings or consultations in the host state's legislative process (Kostecki, Naray, 2007: 25-26).

Commercial diplomats also advise national corporations involved in negotiations with the authorities or other companies from the host state and support in case of contract implementation and problem solving, which refer to activities such as the protection of intellectual property rights, tax issues, and assistance to national companies that have suffered losses and wish to obtain compensation. Commercial diplomats very often discuss these problems during bilateral consultations with members of the government of the host state, usually assisting in the finding of a solution that helps avoid judicial proceedings.

Commercial diplomats' support to firms wishing to enter a new market plays a crucial role in corporate-government relations when the business regime is highly influenced and controlled by local government or the governmental elite. However, information is more accessible for companies today thanks to Internet based information systems and to the improved transparency in business brought about by different organizations such as the WTO or the European Union. Thus, the traditional intelligence function of a commercial diplomat is decreasing at the expense of new forms of promotion events such as trade fairs or trade missions.

\section{DRAWBACKS AND BENEFITS OF COMMERCIAL DIPLOMACY}

Government intervention through economic and commercial diplomacy is criticized by some economists and accused of transferring resources to an export industry that potentially distorts the efficient outcome. Some neoclassical arguments would say that firms should be able to enter foreign markets on their own account and if they have to be aided by governments, then, this is perhaps because of their products are just not good enough. These critics argue that commercial diplomacy implies a transfer of resources from the public sector to commercial activities while is not clear if the private benefits exceed the cost of providing the public service (Yakop, van Bergeijk, 2009: 8-9). Taxpayer's money ultimately finances commercial diplomacy, and if the government subsidizes these inefficient companies, then people's money is wasted. These economists argue that public intervention in both national and international activities of this kind should happen only if the market fails and cannot attain the efficient outcome. 
However, productive firms find many barriers to international trade that need to be overcome, and that is why the use of commercial diplomacy is so important for export promotion. The new emerging economies have very different institutions and cultural backgrounds, and this is already undoubtedly influencing global norms and values, which will indeed have an impact on the rules of international trade and investment. The historical, cultural and institutional background of emerging economies such as China and India may in the long term influence the ways the world defines and settles not only international business but also international conflicts (Yakop, van Bergeijk, 2009: 25-26). Consequently, the role of commercial diplomats is so relevant, since they can be facilitators of mutually beneficial trade and also of good political relationships.

Some would also argue that many of the activities carried out by commercial diplomats would be better performed by private firms or associations that are free of institutional or personal interests. Nevertheless, many are the benefits that the position of commercial diplomats can offer. For example, commercial diplomats have better access to economic intelligence and to CEOs of large firms, policy-makers, bureaucracies and elites in the host country thanks to their position and their embassy's contacts. Exporting firms usually need of information about foreign markets before they try to trade with a firm in another country. The most relevant topics about which firms usually need information include: local consumer preferences and their ability to adapt to new products; the need to adapt products and their marketing to local needs (including language, technical, meteorological, religious and cultural aspects); the reliability of local trading partners; the distribution networks that exist or can be developed; quality standards and legal environmental and institutional requirements; prospects for markets, in particular the niches and products where profit opportunities exist; and the local negotiating and contracting procedures as well as the extent to which contracts are actually enforced (Yakop, van Bergeijk, 2009: 9-10).

Furthermore, as instrument of government policy, commercial diplomacy has the tools to facilitate business and promotion with lower costs thanks to the centralizing support of central government; and diplomats (especially high ranking members such as ambassadors) have great visibility in the mass media and enjoy more credibility than private actors when making promises and commitments during their efforts to attract foreign investors and to guarantee that these relationships will be free from negative political disturbances (Kostecki, Naray, 2007: 16-18). Additionally, the type of imported or exported products may require public sector involvement either on the demand side (for example large infrastructural works) or on the supply side (military or dual use goods), particularly in the case of companies entering emerging markets (Yakop, van Bergeijk, 2009: 9).

Some critics to commercial diplomacy contend that embassies do not charge for their commercial services in many instances. In the past, the majority of services regarding commercial diplomacy provided by government were free. Today, the tendency is to share the burden between the government and the companies seeking help to export. General information and counselling provided are usually free, but personalized service, such as participation at trade shows and trade missions or special market analysis lead to charges. As for foreign investors, TPOs/IPAs usually do not charge for 
the provision of their services (Mercier, 2007: 9-10). Charging for some services, such as market research and other forms of consulting, may act as a first filter to companies that are truly interested in investing in such market. Charging may also ensure service quality, reduce the ineffective allocation of public funds, and avoid preferential treatment of commercial diplomats to their private friends. However, by monetizing all services offered by commercial diplomats, their performance would be measured only by economic terms and results and they would be evaluated both by business managers and by governments. Nevertheless, performance can be measured by many other different indices, such as the number of clients, the industry's feedback, the client loyalty, the generated revenue, and the growth experienced by the clients of the commercial diplomacy services. The evaluation might also include an analysis of the success of the commercial diplomat's assistance in solving problems or fulfilling government objectives.

\section{FACTORS THAT DETERMINE THE ROLE OF COMMERCIAL DIPLOMACY}

Public sector involvement is an essential condition for companies that want to access new markets and therefore a useful instrument to reduce or eliminate cultural non-tariff barriers to trade and investment. Moreover, diplomatic representation may provide a superior level and quantity of trade-and-investment-related knowledge. When opening new and distant markets, enterprises need commercial diplomacy services that facilitate their entry and the interaction with new business cultures and authorities, especially in the case of small and medium sized companies (SMEs) that are newcomers to a particular region and have not any experience of the kind. These services will be very influenced by relevant factors in bilateral exchanges such as a common border, a common language, a common currency, or an (ex) colonial relationship; but also individual country characteristics such as the area of the economy or the fact that it is in an island economy. Another aspect that shapes commercial diplomats' role is the environment for bilateral business. Commercial diplomats have to deal with bilateral relations that come marked by factors such as history, political proximity, military alliances, etc. When the two states in question are members of a common regional group, such as free trade area or customs union, commercial diplomats' job is much facilitated. At the same time, when a state joins one of these groups, the duties of commercial diplomats operating in them become obsolete and diplomats have to modify their responsibilities in order to adapt their country business people's needs to the new situation.

Nevertheless, the success of commercial diplomacy is not based on a perfect formula that can be spread and applied everywhere regardless of cultural, economic, historical and political backgrounds. Kostecki and Naray distinguish two different variables at play that determine the weight of the various commercial diplomacy activities: exogenous (host state) and endogenous (home state) to the national service of commercial diplomacy (Kostecki, Naray, 2007: 12-16).

The exogenous variables include host country characteristics such as market size and potential, the location of a particular centre of gravity (if any), business style 
and governance, home state characteristics (such as the level of economic development, mobility of managers, IT use and attitudes towards business), and the nature of bilateral relations between the home and the host country. The host state's market size and market potential is the most significant determinant of the investment in commercial diplomacy. Indeed, target countries with large and rapidly growing markets, such as Brazil, China, India, Russia or Eastern Central European states, tend to attract more commercial diplomacy activities than countries with small markets and limited growth.

As per the endogenous variable, all countries, and especially developing ones, are very concerned about how their economies are perceived in other states. Because of that, commercial diplomats are frequently involved in long term State policies aimed at strengthening their country's image with the planning, encouragement and coordinated management of activities carried out by all public and private agencies. These policies seek to promote a stronger image of their country in general and of their State economy in particular. These activities, in which commercial diplomats are involved, include tourist campaigns, 'made-in' promotion, and meetings with potential investors to explain policy reforms that will attract foreign business.

The different characteristics of a country not only influence the results of commercial diplomacy but also determine what instruments are more effective. Van Veenstra et alt. analyzed the impact of different tools of export promotion in 36 countries in the year 2006 (Van Veenstra et alt., 2010: 1-19). The first of their conclusions is that the number of diplomatic missions appears to be important for countries with middle and high incomes per capita, but not for the low-income group. As for their study, diplomatic missions are effective only in increasing exports from developed countries to low-and middle-income economies, but not to other high-income economise. Consequently, developed countries should not expect an increase in their bilateral trade by opening new embassies and consulates in other developed countries. Secondly, their study also concludes that the overall effect of export promotion agencies is insignificant for OECD countries, because these do not stimulate exports to low-and middleincome countries and even have a significant negative influence on bilateral exports to other high-income countries. However, TPOs/IPAs are an efficient tool for increasing bilateral export of developing countries with countries of any income. These organizations or agencies are often located within the exporting country and support firms in the internationalization of their business and to improve the performance of their exports. Furthermore, they carry out different market researches, marketing campaigns and publications that help to create a positive image of the home country abroad (Van Veenstra et alt., 2010: 1-19).

In conclusion, instruments of commercial diplomacy have relevant impact on exports for low-and middle-income country, and, on the other hand, embassies and consulates play a better role for developed countries than for the developing group. Therefore, if commercial diplomats want to be effective, they should know which instruments employ depending on the level of development of the exporting and importing states. Nevertheless, the role of commercial diplomacy is probably more important for the international economic relations of developing countries for different reasons. Firstly, because the level of knowledge across countries inside the OECD is quite 
larger than across developing countries, so the generation of public knowledge would be expected to be especially relevant in the North-South and South-North relations. Second, trade-related institutions are less well developed in non-OECD countries, so the role that government plays in trade relations is meant to be more relevant in these countries than in the developed world. Third, access to market information is easier and more transparent for developed countries so commercial diplomacy is not as relevant in trade between them as would be expected for developing countries where factors such as different business practices or lack of information about competitiveness and reliability may increase the cost of market research. And fourth, embassies and consulates are particularly important in the starting up phase of international trade and investment relationships. These diplomatic missions have a high value added in trade between developed and developing countries since emerging markets are supposed to face more difficulties in export facilitation and with market failures, and therefore commercial diplomacy is expected to become an essential tool in the close future to solve problems related, among other things, to these market failures (Yakop, van Bergeijk, 2009: 21).

\section{STRUCTURES OF COMMERCIAL DIPLOMACY}

Diplomacy has been traditionally monopolized by the central or federal governments, and in many countries the Ministry of Foreign Affairs was initially the main responsible for all economic issues, including commercial diplomacy. However, in the recent past, and after the reorganization of the diplomatic system, the commercial activities of central governments have become more centralized (Mercier, 2007: 3-4) and today the Ministry of Foreign Affairs sees its influence and role in commercial diplomacy diminished in favour of ministries specialized in economic and financial matters and supported by central governments. Currently economic and commercial diplomacy is handled in most cases by the Ministry of Economy and Trade.

Moreover, with the progressive decentralization of power to provincial governments, regional levels of government have come to play an active role in pursuing commercial diplomacy and these newly-empowered regional and local entities have become involved in their own international ties and maintain separate mechanism from the governmental ones to satisfy their local-specific interests in different areas. The best example of this are probably German Landers that have opened representative offices in Brussels in order to influence decision making at the EU Commission and EU related institutions (Saner, Yiu, 2003: 12-13).

The government approach toward business varies considerably between states and strongly influences commercial diplomacy. For instance, in the United States and Switzerland, where government intervention has been traditionally low, exporting corporations have fewer expectations regarding export promotion than firms coming from countries where government intervention has been traditionally more present, as in Canada or in the Scandinavian countries. For certain nationalities, such as Swiss business people, it is normal to act alone, whilst others, such as French, tend to contact host country diplomats. This disparity is caused by many factors such as managerial 
expectations of what can be obtained from a commercial diplomat, perception of the role of the state in business development, and cultural considerations (Kostecki, Naray, 2007: 15-16). Thus, the structure of commercial diplomacy varies from one country to another. Mercier distinguishes three main factors that have an impact on the way in which export promotion is carried out (Mercier, 2007: 4-5).

The first one is the country character. Not all states adopt a purely governmental structure of commercial diplomacy. Some opt for public character; others for private character; and the most of governments welcome support from the private sector to integrate it into their structure and adopt a mixture of both: this is a public-private organizational model.

The second factor is the level of government where services are provided. There are organizations at the central, regional and local levels that provide export promotion services. For many states, although regional and local governments also may play a role, it is the central government that normally coordinates actions and fulfils more of the export promotion. However, in the case of some federal states, it is regional governments that are in charge of export promotion. A good example of this is the case of Belgium, where it is mainly the regional authorities of Flanders, Wallonia and Brussels that are entrusted with this task.

In third place, the number of departments or ministries that share the management of commercial diplomacy within the governmental structure also determines the process in which commercial diplomacy is carried out. Some countries have created one consolidated ministry by merging their Ministry of Foreign Affairs with their Ministry of Trade. This is the case of Austria, Belgium, Canada and Sweden. In other countries, to coordinate export promotion, the government has created a joint body of the Ministry of Foreign Affairs and the Ministry of Trade. This happens in the United Kingdom and the Czech Republic. There are other countries, such as the U.S., where it is the Ministry of Trade/Commerce that is still primarily (but not exclusively) responsible for export promotion. Other governments, like in Singapore, opt for establishing special entities, and in some, as in Austria, the chambers of commerce and not the government have the responsibility to provide the commercial diplomatic services.

The promotion of FDI is usually done through investment promotion agencies (IPAs), an instrument relatively new that has grown in popularity in the last three decades. However, not all countries possess national TPOs/IPAs and the way FDI is promoted also varies around the world. Some developed countries, although also some emerging countries such as China, have created sub-national IPAs which are addressed not to decide about which country to invest in, but where to invest within a country. These sub-national IPAs, especially frequent in federal states, are agencies that work to promote regions, provinces or states, and are often independent organizations and not subsidiaries of the national IPA, which can lead to competition between them for the same investment if coordination and collaboration are not well organized. In recent years, even some led major cities that are often the main economic motors of entire regions or even countries, such as Montreal or London, have created their own IPAs too.

Similar to export promotion, the core decision when establishing the structure of promotion of foreign investment regards its nature: public, private or a mixture of both (Mercier, 2007: 6-7). Some tasks of investment promotion are best performed 
by private organizations and there are other tasks that are usually better executed by government organizations. Therefore, the choice of structure is in fact an important decision. The vast majority of countries choose a form of governmental structure, because investment promotion is considered a public good. However, IPAs need some independence from the government and an increasing number of them have autonomous governmental body, joint private-public, or private structures.

Export promotion strategic approaches adopted by countries also differ around the world. These approaches can be integrated or loosely coordinated. While some governments target specific markets projects and assist companies for a specific period of time, other countries instead prefer to offer an array of services that are loosely coordinated and are available generally for most or all companies (Mercier, 2007: 6-8). Regarding inward investment, the strategic approach depends on the core objectives or functions adopted by IPAs, that usually are image-building (especially important for developing countries), investment services, and investment generation.

Most states target specific sectors for export promotion and for inward investment. However, the sector to be targeted varies depending on the level of development of the country concerned. Developed countries for example are highly interested in those sectors related to innovation and what is called the knowledge-based economy (Mercier, 2007: 7). In any case, governments usually target small and medium-sized enterprises because they usually lack the financial resources and the information that are necessary to expand further and to stop being potential exporters and become real exporters.

When targeting companies for inward investment, SMEs attract more attention than transnational corporations (TNCs), which are thought to have sufficient resources to work without the support of IPAs. However, major companies are not ignored and they are sometimes precisely targeted because they might create a lot of jobs, which makes it more cost-effective for commercial diplomats (Mercier, 2007: 7-8). Who the main beneficiaries of commercial diplomat's services are also depends on the countries and circumstances concerned. Most commercial diplomacy services focus on SMEs, which are offered more technical and diversified and less relationship-based services, while big corporations are more interested in how to start and maintain public relations with the host state's government and private sector personalities. In addition, special attention is paid to newcomers and to areas of business which have been targeted by the government as important, because they are thought to be promising in terms of job creation, regional development or R\&D.

Mercier also divides the programs that can be used by governments to pursue export promotion into two categories: export service programs and market development programs. The first category includes seminars for potential exporters, export counselling, how-to-export handbooks, and export financing. The latter category includes dissemination of sales leads to firms, participation in foreign trade shows, preparation of market analysis, and export newsletters (Mercier, 2007: 7-8).

Regarding inward investment, governmental agencies employ practices such as advertising, direct mailing, investment seminars, investment missions, matching prospective investors with local partners, or participating in trade shows and exhibitions. Trade shows and missions are believed to be the most effective practices when the government is actively involved. These take place at a fixed location overseas, where 
firms have the chance to exhibit their products in a stand for the duration of the show. These fairs allow the participants to gain knowledge of a foreign country's culture through direct contact with local business persons and government representatives. They are an exceptional instrument to enter foreign markets and have become very popular in the recent past due to the decrease in the cost of air transport. Politicians from central and sub-national government usually join export promotion professionals during these trade missions (Mercier, 2007: 8-9).

There are other aspects that can determine the quality and relevance of commercial diplomat's work. For instance, the resources of the foreign post: such as budget, number of employees, business network and communication facilities. Preparedness of the client firm and the readiness to pay for the service can also influence commercial diplomacy effectiveness. In order to participate effectively in the service creation process clients should acquire previously some knowledge and skills so commercial diplomats could count on, at least, a moderate level of participation, for example during trade missions. Moreover, the environment in which diplomacy is conducted has important effects on the outcome of commercial diplomats' work. Foreign firms sometimes face unfavourable institutional environments which are difficult to adapt and to operate with, such as changes in national legislation or ongoing armed conflicts in the commercial area where they operate. Under these circumstances, firms may have more need of commercial diplomacy than when operating in more favourable institutional environments (Ruel, Zuidema, 2012: 12).

\section{TYPES OF COMMERCIAL DIPLOMATS}

In all cases, commercial diplomats should have some common competencies. They need to have firsthand knowledge and experience of the functioning of the area of bilateral and multilateral diplomacy and international relations in general; and of the intergovernmental bodies and the central governments or key ministries in particular. Diplomats should also be able to understand the different legal, cultural, political and economic systems that differ from the dominant form of the Western capitalism. Thus a commercial diplomat should be competent to converse with opinion leaders and politicians representing at times diametrically opposing religious, political and cultural systems. Obviously, a good commercial diplomat should also know how to defend the interests of their respective state in both private and official discussions, in negotiations with opinion leaders or in front of the media or through communication channels such as newspapers and conferences. Moreover, diplomats have to learn new styles of leadership and influencing strategies in order to successfully shape complex negotiation processes at international level (Saner, Yiu, 2005: 34-36).

However, commercial diplomats often have different styles based on their approach to commercial issues and their leading concerns. As per Kostecki and Naray's classification, three basic types of commercial diplomats can be suggested: business promoter, civil servant and generalist commercial diplomat (Kostecki, Naray, 2007: 21-22).

The major role of business promoter is to provide the consultancy-like services requested by business firms. They are business-oriented, pro-active commercial dip- 
lomats that work to satisfy companies served rather than the ministry. They have solid business knowledge and an entrepreneurial approach. They usually operate in the capital of a host state, supported by branches in the main industrial regions. Their consultancy services are offered free of charge in most of cases.

Civil servants' main concern is how to please the Ministry of Trade of the sending state. These commercial diplomats often emphasize policy implementation rather than business support; that is that they respond more to government instructions than to client needs. They keep their distance from business deals and tend to be reactive rather than pro-active.

Generalist commercial diplomat is a career diplomat less technical than the two former types. The generalists perceive commercial issues in a broader diplomatic and political sense and their main concern is how they can please the Ministry of Foreign Affairs of the sending state. They tend to assume business support functions on and ad hoc basis or in addition to other diplomatic duties. They have good contacts (especially at ambassador level) and place commercial diplomacy activities within a broader context of the foreign aid programs and national diplomacy (Kostecki, Naray, 2007: 21-22).

Since commercial diplomats may have different roles, styles and approaches, they tend to have different educational backgrounds and professional experience too. Business providers are expected to have both business training and education, and direct experience in the private sector. As for civil servant commercial diplomats, they often have Trade Ministry and some economic or commercial schools training rather than business experience and direct business know-how. With respect to generalist diplomats, they learn by doing and rarely have business education or direct business experience. They are rather interested in policy issues which may facilitate their work with other ministries and in dealing with trade regulation and advocacy (Kostecki, Naray, 2007: 24).

In the past commercial diplomats used to act as civil servants. However, this was not fully effective because they tended to bring practices of government bureaucracy to foreign posts when dealing with business needs. On the contrary, business promoters usually have an entrepreneurial approach and a solid technical know-how in international marketing. They display more empathy for the client and are often less involved in politics than civil servants and generalists. This is why business promoters are often considered the most successful commercial diplomats. Other commercial diplomats with experience acquired while serving at foreign pots, such as embassies, or who have other background (for instance when they know the country's language or culture, or when they have links that can reinforce their political influence) can also contribute to commercial diplomacy very much (Kostecki, Naray, 2007: 24-25). Therefore, the style and background of commercial diplomats are very relevant for the quality of their services.

Some diplomats are placed in business settings for short periods of time, while business representatives take temporary postings in diplomatic missions (Mercier, 2007: 10). Job rotation into the world of commercial diplomats and out into the area of business and education is something common, especially in countries such as France, the United Kingdom or the United Sates. Probably the best example is Henry Kissinger, a former professor at Harvard University who became first National Security Adviser, later Secretary of State, then went back to university, and finally created a consulting firm that 
offered his services, among others, to the government of George W. Bush. But there are also others who follow the opposite route, from the Foreign Service to business appointments, as is the case of many ambassadors who get appointed by global companies as International Relations representatives, or who become members of law firms, investment firms, consulting companies or policy advisory agencies (Saner, Yiu, 2005: 28-29). This is the case of John Robert Bolton, who after serving as U.S. ambassador to the United Nations from August 2005 until December 2006 was appointed senior fellow at the American Enterprise Institute, senior advisor for Freedom Capital Investment Management, and counsel to the law firm Kirkland \& Ellis (Saner, Yiu, 2005: 6-7).

Investment in professional commercial diplomats is today more important than ever due to the process of globalization and its complexities. However, cross-fertilization fails often due to the lack of enough professional diplomatic staff and also because of the appointment of non-diplomats to ambassadorial postings for political favours and nepotistic empire building strategies and not for personal merits.

$$
* * *
$$

Globalization has brought competition between states for Foreign Direct Investment. On one hand, countries push each other to gain market access for their national companies and attempt to protect their domestic markets by covert or overt trade barriers. On the other hand, at the same time, states need to work together at rule setting intergovernmental institutions such as the World Trade Organization (WTO) or within the context of regional economic agreements such as North Atlantic Free Trade Agreement (NAFTA). Under this rapid process of globalization, international companies have to explore new economies where the formal regulatory and institutional context for doing business differs from the one that they are accustomed to, and this often needs an active participation of the state. In order to support their home firms in their internationalization, governments need to adopt (and adapt) diplomacy and its capabilities, including training their representatives in what is known as commercial diplomacy.

Commercial diplomacy represents the effort of governments to promote country business abroad and to attract Foreign Direct Investment using diplomatic channels and processes. Commercial diplomacy's final goal is gaining access to new markets and serving the home state economy. In order to achieve that, corporate diplomacy combines the interest of both government and business not only by trade and export promotion but also by exploring new markets and investment opportunities. Commercial diplomats may be of much help to private companies that need information gathering, support and promotion during negotiations. Commercial diplomats have access to commercial intelligence that would be unavailable for firms if they had to gather it themselves. Moreover, thanks to their position and relevance, activities carried out by commercial diplomats are more visible in the media and therefore may draw more attention at a lower cost for the firms than the traditional marketing practices. Commercial diplomats have also often a better access to political and financial networks and influential access to high-level contacts than most companies can do individually, especially in the case of small and medium sized-firms. 
Commercial diplomacy generally focuses on SMEs because these have a higher exposure to trade barriers in their internationalization efforts compared to the larger organizations due to their limited financial resources and skills to gather market information and to contact potential overseas customers. Since commercial diplomacy is government driven, it usually enjoys of a high trust and helps attract Foreign Direct Investment, and, in addition, the centralization of the information gathered increases its efficiency for the sector.

Developing economies are going to attract more attention in the coming years and will be given a higher priority by Ministries of Foreign Affairs and international firms, and therefore commercial diplomats and their activities are expected to gain progressively relevance. Diplomats' experience, approach and origin; size and preparedness of firms to start doing business in a host state; industry-specific characteristics; home and host state development; and types of business and state promotion; are some of the several factors that determine the impact on long-term export sales, growth and employment levels, and the intensity and relevance of commercial diplomacy and business diplomacy implementation.

All these circumstances should be taken into consideration when commercial diplomacy is established, organized and implemented, if both governments and firms want to outlive the continuous and rapid changes in a progressively more globalized business environment.

\section{BIBLIOGRAPHY}

Berridge G. R., James A. (2001), A Dictionary of Diplomacy, Basingstoke.

Black J. (2010), A history of diplomacy, London.

Ford C. (2005), Commercial Diplomacy: The Next Wave, „Foreign Service Journal”, Vol. 82, Issue 4.

Hamilton K., Langhorne R. (2011), The Practice of Diplomacy: Its Evolution, Theory and Administration, London.

Kostecki M., Naray O. (2007), Commercial diplomacy and international business, „Clingendael Discussion Papers in Diplomacy”, No. 107.

Mercier A. (2007), Commercial Diplomacy in Advanced Industrial States: Canada, the UK and the U.S., „Clingendael Discussion Papers in Diplomacy”, No. 108.

Riordan S. (2014), Business diplomacy: shaping the firm's geopolitical risk environment, „Policy Brief".

Ruel H. (2015), Business diplomacy: a definition and operationalization, „Windesheim University of Applied Sciences".

Ruel H. (2013), Diplomacy means business, „Windesheim reeks Kennis en Onderzoek”, No. 46.

Ruel H., Zuidema L. (2012), The effectiveness of commercial diplomacy: A survey among Dutch embassies and consulates, "Clingendael Discussion Papers in Diplomacy", No. 123.

Ruel H., Lee D., Visser R. (2013), Commercial Diplomacy and International Business: Inseparable Twins?, „Academy of International Business”, Vol. 13, No. 1.

Saner R., Yiu L. (2003), International Economic Diplomacy: Mutations in Postmodern Times, „Clingendael Discussion Papers in Diplomacy”, No. 84.

Van Veenstra M., Yakop M., van Bergeijk P. (2010), Economic diplomacy, the level of development and trade, „Clingendael Discussion Papers in Diplomacy”, No. 119. 
Yakop M., van Bergeijk P. (2009), The weight of economic and commercial diplomacy, „International Institute of Social Studies Working Paper", No. 478.

\begin{abstract}
The beginning of 21 st century has witnessed the consolidation of a process of globalization, where since the 1980s the hegemonic position of the United States has weakened and the international environment is moving towards a multipolar system with emerging economies adopting an increasing power. In this context, new non-state actors, such as non-governmental organizations or multinational firms, have adopted an important role in the stage of international relations that in the past was limited to states and international organizations. The globalization process forced firms to operate internationally, and the financial crisis started in 2008 provoked the contraction of domestic markets and obliged governments and many firms from industrialized economies to look beyond the limits of their home states if they wanted to survive and benefit from the enormous opportunities offered by the new potential foreign markets. In order to achieve this, both governments and multinational firms should adapt diplomacy and its capabilities to their own specific needs. Commercial diplomacy includes policies, practices, instruments and organizational structures that governments and multinational firms should adopt at different levels to survive in today's rapidly changing global business environment. Only by interacting between them and with the rest of actors within the international sphere, states and multinational firms will benefit from the switch in the balance of economic power.
\end{abstract}

Keywords: commercial diplomacy, globalization, governments, multinational firms, emerging markets

\title{
DYPLOMACJA W ZGLOBALIZOWANYM ŚWIECIE
}

\section{STRESZCZENIE}

Początek XXI wieku to konsolidacja procesu globalizacji, w którym od końca lat 80 . XX wieku hegemoniczna pozycja Stanów Zjednoczonych została osłabiona, a środowisko międzynarodowe zaczęło zmierzać w kierunku systemu wielobiegunowego charakteryzującego się wieloma gospodarkami wschodzącymi. W tym kontekście nowe podmioty niepaństwowe, takie jak organizacje pozarządowe lub międzynarodowe firmy, których rola w przeszłości była ograniczona, zaczęły zyskiwać na znaczeniu. Proces globalizacji spowodował, że firmy stawały się coraz bardziej widoczne na arenie międzynarodowej. W szczególności kryzys finansowy rozpoczęty w 2008 roku wywołał załamanie rynków krajowych i spowodował, że wiele firm zaczęło spoglądać poza granice swoich państw, chcąc przetrwać i skorzystać z ogromnych możliwości oferowanych przez potencjalnie nowe rynki zagraniczne. Dlatego, aby jeszcze bardziej realizować swoje cele, zarówno rządy, jak i transnarodowe przedsiębiorstwa powinny dostosować narzędzia dyplomacji i jej zdolności do własnych potrzeb. Z tego względu tak ważne jest, aby dyplomacja korporacyjna łączyła w sobie elementy polityki, praktyki oraz instrumenty i struktury organizacyjne. Tylko w ten sposób można przetrwać w dzisiejszym szybko zmieniającym się globalnym środowisku biznesowym. Tylko przez interakcje zachodzące między nimi oraz pozostałymi podmiotami na arenie międzynarodowej, państwa i międzynarodowe firmy będą w stanie korzystać ze wspomnianej zmiany odnoszącej się do światowej gospodarki.

Słowa kluczowe: dyplomacja korporacyjna, globalizacja, rządy, transnarodowe przedsiębiorstwa, rynki wschodzące 